\title{
The emerging geographies of climate justice
}

\author{
Susannah Fisher
}

June 2012

Centre for Climate Change Economics and Policy

Working Paper No. 94

Grantham Research Institute on Climate Change and the Environment

Working Paper No. 83 
The Centre for Climate Change Economics and Policy (CCCEP) was established by the University of Leeds and the London School of Economics and Political Science in 2008 to advance public and private action on climate change through innovative, rigorous research. The Centre is funded by the UK Economic and Social Research Council and has five interlinked research programmes:

1. Developing climate science and economics

2. Climate change governance for a new global deal

3. Adaptation to climate change and human development

4. Governments, markets and climate change mitigation

5. The Munich Re Programme - Evaluating the economics of climate risks and opportunities in the insurance sector

More information about the Centre for Climate Change Economics and Policy can be found at: http://www.cccep.ac.uk.

The Grantham Research Institute on Climate Change and the Environment was established by the London School of Economics and Political Science in 2008 to bring together international expertise on economics, finance, geography, the environment, international development and political economy to create a world-leading centre for policyrelevant research and training in climate change and the environment. The Institute is funded by the Grantham Foundation for the Protection of the Environment, and has five research programmes:

1. Global response strategies

2. Green growth

3. Practical aspects of climate policy

4. Adaptation and development

5. Resource security

More information about the Grantham Research Institute on Climate Change and the Environment can be found at: http://www.Ise.ac.uk/grantham.

This working paper is intended to stimulate discussion within the research community and among users of research, and its content may have been submitted for publication in academic journals. It has been reviewed by at least one internal referee before publication. The views expressed in this paper represent those of the author(s) and do not necessarily represent those of the host institutions or funders. 


\section{The emerging geographies of climate justice}

\section{Susannah Fisher}

Climate justice is a well-used concept within the international climate debate yet it has often remained little more than a static ideal. This paper brings together literatures on environmental justice, development processes, and the politics of scale to argue that we need to be more attentive to the emerging geographies of climate justice, particularly in the global South where climate change provokes questions of uneven development processes as well as environmental concerns. Through an analysis of India's climate policies and politics, as well as empirical work with civil society networks mobilising around climate change I make three arguments. Firstly, I show how climate justice has been scaled as an international justice issue through public discourses, national policies and civil society engagement in India. I show how this political scaling of climate justice as international has become institutionalised and civil society actors engage with climate justice issues at different scales within this framework. I argue that this institutionalisation narrows the political space for alternative articulations and claims for climate justice. Secondly, whereas climate justice has tended to focus on the nation-state as the key actor in addressing climate injustice I argue that this paper demonstrates the importance of a critical stance towards both state and non-state actors as both champions of justice and perpetrators of injustices. Lastly, I argue that there are multiple spaces for climate justice claims that go far beyond the state and the international fora. To understand what is meant by climate justice beyond the policy rhetoric requires an exploration of the multiple manifestations and scales of climate justice and geographers could offer a critical contribution to an understanding of what national and local climate justice would mean in practice. 


\section{Introduction}

Climate justice has become a rallying cry for governments in the global South, as well as for indigenous communities facing environmental change, and NGOs seeking to instil a set of principles into the climate debate (Featherstone 2003; Parks \& Roberts 2008; Fisher 2012a; 2012b). As such, it is widely used by different actors seeking to characterise their position as the equitable one. Climate justice however, is not only about the distribution of environmental goods between nation-states but also about how such goods continue to be distributed at national and local levels under conditions of climatic change, as well as the importance of recognition and participation (Schlosberg 2004). In the global South, it is not only about environmental justice but also an uneven development process (Ferguson 1990). Whilst the environmental justice literature has deconstructed the term into a locally contingent one, contextually dependent and constructed across scales (Williams \& Mawdsley 2006; Walker 2009; Mason 2011), literatures on climate justice and development have yet to engage more seriously with the construction of justice beyond a static ideal. This separation between justice literatures on the environment and development processes more broadly reflects the perceived division between the "environmentalisms of the poor" and the environmental concerns of the richer nations (Guha \& Martinez-Alier 1997). Climate change as an issue however transcends these binaries with countries such as India manifesting multiple environmentalisms and positionalities in a debate that transcends scales from the local to the transnational. However, concepts of climate justice so far have not attended seriously to the issue of scale and spatiality nor have scholars or activists engaged with the claims for multiple climate justices that go far beyond inter-state justice claims at the United Nations Framework Conventions on Climate Change (UNFCCC). This paper addresses this gap by bringing together literatures on environmental justice, development processes and the politics of scale to develop a more nuanced concept of multiple climate justices attentive to the construction of scale as a political project as well as the grounded realities of justice claims. Through empirical work with non-state climate change networks and analysis of climate policies in India I argue that the international scale of the climate justice debate has shaped the political space for climate justice claims and has excluded the diverse experiences of communities and individuals with climate vulnerability, second-order effects of climate 
policies, and interacting spheres of inequality. Whilst this initial scale of the international has been a logical way to open up this debate and campaign for inter-state equality, as the implications of both climate change and its policy responses unfold it is important to reconceptualise spaces for climate justice to take into account the multiple ways it will impact on development experiences.

Environmental justice, development processes and the politics of scale: what can we learn for conceptualising climate justice?

The terms climate justice or equity (broadly used in the debate to mean distributive justice) have entered the public discourse through a concerted effort on the part of governments in the global South (of which India was a prominent player) to have recognised the different historical responsibility for causing climate change, and therefore the differing responsibility to address it either through reducing emissions or contributing financially to adaptation measures. This principle has become embedded within the United Nations Framework Convention on Climate Change through the principle of "common but differentiated responsibilities" (see Fisher 2012a). Scholars have rushed to catch up with the terms of the debate and work has largely focused on the philosophy or ethics of climate justice (Page 2006) and the implications of justice and equity for the international regime (Parks \& Roberts 2008; Posner \& Weisbach 2012; Soltau 2009). Some scholars have also addressed the embedded justice implications of the emerging commodification of carbon and the local injustices of climate policy such as the Clean Development Mechanism (CDM) (Newell \& Paterson 2010). Whilst almost all of this has focused on mitigation, emerging work such as Paavola and Adger (2006) addresses the justice implications of adaptation, mainly focusing on the procedural aspects. Climate justice also offers many new angles to a theorisation of justice, such as inter-generational justice and justice between species (Okereke et al. 2009). However, work so far has lacked the analytical focus and detailed spatial deconstruction of that on environmental justice. There has been a focus on existing institutions and the concept of justice enshrined through the UNFCCC rather than a retheorisation of what climate justice might mean beyond the policy terminology or the binary of North-South relationships. 
In this paper I bring together aspects of three literatures (environmental justice, development processes and the politics of scale) to conceptualise the geographies of climate justice beyond the international scale and consider what a more spatial understanding of climate justices might offer the climate debate. I argue that ideas within each of these literatures can help conceptualise the multiple forms of climate justice that are beginning to unfold within and across nations, and offer a new way to think about multiple justice claims opening up an analysis of how and why certain claims to climate justice are privileged within the current framing. There has been extensive debate on how to conceptualise justice, building on and extending the Rawlsian ideal of distributional justice. Political theorists have debated the relative roles of distribution, recognition, participation and capabilities in creating a just society (see for example Sen 2009; Fraser 2000; Nussbaum 2006). It is not my purpose to critique the political theorising of justice in this paper, but to explore how the particular usage of climate justice delimits the policy and civil society mobilisation around this issue, and narrows down much of the above political debate on justice to one particular framing despite the theoretical critique of such an approach (see Adamian 2008). In this paper I follow the conceptual space for justice as outlined by the critical pluralist approach of Schlosberg $(2004 ; 2007)$ using three dimensions of justice: distribution, recognition, and procedure. He suggests that beyond the distributive effects of justice, recognition and respect of the diverse actors involved and participation in decision-making, are all important aspects. Finally, this paper focuses on justice claimmaking from spatially grounded experiences through political processes and civil society networks. It should be noted that this is only one aspect of how climate justice or claims for injustice can materialise. The spaces (or lack of spaces) for claim-making are also partially defined by the surrounding technocratic discourses of efficiency and effectiveness or nonclimate related discourses and practices, as well as the politics of who can make claims (Castree 2010). Despite this, using justice claim-making allows an examination of what spaces are deemed to be open for climate justice and how civil society actors and the state seek to mobilise climate justice as an issue. This also allows analysis of the "non-claims" that are left unarticulated as I discuss later.

I now turn to three literatures that deepen our engagement with conceptualising the emerging geographies of climate justice. 


\section{Environmental justice}

Environmental justice has been a central topic of geographical debate since its emergence through US experience with environmental racism in the 1970s (Sze \& London 2008). This "first generation" environmental justice literature has focused on siting of environmental costs and the role of race and gender. It has been largely local in scope, and drawn particularly from the historical US experience and that of social movements. This literature mainly focused on distributive aspects of justice, the actual distribution of environmental costs and benefits, rather than other aspects now understood by other scholars as part of a complex picture of justices. Beyond deconstructing aspects of justice, scholars have also moved to understand the spatiality of justice working at different scales with a multiplicity of justice concerns and claims (Walker 2009). The subjects of environmental justice research have also expanded from toxic waste and hazards, to different types of local problems as well as global environmental issues (Walker and Bulkeley 2006). The way environmental justice is conceptualised contains embedded notions of the scale of the problem and the geography of responsibility and therefore opens up the space for negotiation in some arenas but not others. A local toxic waste site for example is constructed inherently as a local issue, where the injustice implications are local in scale. Global greenhouse gas emissions on the other hand are constructed as a nationstate site of responsibility with climate injustices conceived of at the inter-state level.

Debates on environmental justice have largely drawn on research from the industrialised countries and Williams and Mawdsley (2006) emphasise the need to consider if western framings of environmental justice provide the "appropriate frameworks for action, and theoretical purchase on the complex realities of poorer countries" (p661). As norms and ideals of environmental justice diffuse through international law, or activist movements these questions become ever more pressing. Of course countries such as India have their own rich tradition both of fighting injustices and theorising its implications (see for example Gadgil \& Guha 1995; Baviskar 2002), and such insights may broaden western theorising of different forms of justice. Williams and Mawdsley suggest that there is lack of recognition within participatory structures in a public sphere dominated by middle-class actors and shaped by structural inequalities in the post-colonial state. Whilst debates on environmental justice have been largely focused in the industrialised nations, work in 
development studies has been uncovering grounded experiences of development and justice in different locations.

\section{Development processes}

Debates in development studies and development geographies have provided rich insightful commentaries on experiences of justice and injustice as well as theorising justice from a livelihood perspective. Amartya Sen has made a seminal theoretical contribution to this line of thought with his book-length treatment of ideas of justice, building on his earlier "capabilities" approach stressing the importance of freedom to engage in society (2009). Sen argues that justice theorising must move away from a focus on institutions and rules to how justice is realized, he also suggests that justice must be comparative. However, despite this theoretical engagement and empirical explorations of structural inequality and power relationships (see Chambers 1990; Mosse 2005; Li 2007), justice concepts have rarely been grounded or explored through their multiple spatialities in the context of development research. This body of work has much to offer a more grounded understanding of multiple climate justices.

To elucidate further the potential contribution of development geographies to more rooted understandings of justice I use some two streams of work on relationships with the state and on processes of participation and marginalisation. There are of course many facets of development research that could shed some light on this debate, and these bodies of work provide two perspectives from which to consider the contribution of more grounded analyses in different geographical locations. Participation has been a topic of long debate since the seminal contributions by Chambers and others (Chambers 1990; Cooke \& Kothari 2001; Mosse 2005) on incorporating the "objects of development" within decision-making, The discourse of participation has become increasingly contested with debate centring over its role as a legitimating strategy for hegemonic interest or its ability to effect transformation (Hickey \& Mohan 2004). This work has engaged with the politics of difference (Young 1993) and the project of development as one of social justice (Mohan \& Hickey 2004). Thinking through this literature with Schlosberg's definition of distribution, procedure and recognition shows that there are multiple instances where once aspect of justice might be overlooked in favour of another. For example, do categories and activist 
strategies on the issue lack true recognition of marginalised communities? What injustices currently suffered might become celebrated as "solutions" under climate change? These are questions I do not seek to answer in this paper but I show how conceptualising climate change justices in a new way taking account of these aspects will offer an analytical path to open up these questions.

There has been considerable work on the experiences of marginalised communities with the State that can also deepen an engagement with ideas of climate justice (Scott 1985; Corbridge et al. 2005; Veron 2006). Chatterjee (2004) notes the tension between marginalised communities and the State in that they tend to meet the State whilst negotiating legal practices to survive, whilst Ferguson (1990) in his work on the anti-politics machine in Lesotho observes the use of development processes to extend bureaucratic power over local communities who may rebel against the state. Amita Baviskar questions the role of the State in creating injustices for poor communities in Delhi through her work on urban planning processes for the Commonwealth Games in 2010 (2011). She suggests that this "spectacular event" allowed the municipal authorities to override normal planning procedures to enact regressive policies on the city. These brief examples highlight that concepts of climate justice need to take into account the complex relationship of communities with the State. No one actor can be the source of climate justice or injustices. The literature also emphasises the lack of recognition given to some actors within the public sphere and the need to be alert to the participatory and distributive aspects of justice if recognition and respect are not included. A lack of an explicit justice framing can lead to these diverse development experiences being left out of the broader discussions of both environmental and climate justice. We need a way of conceptualising climate justice that overcomes this dichotomy and bring together the rich insights from development research with those on environmental justice, to understand what might be meant by climate justice in different contexts.

\section{Politics of scale}

The third literature that has much to offer this discussion is that loosely termed the 'politics of scale'. This has been an extensive and long-running debate in geography and it is not my purpose to review this here (for this discussion see Marston 2000; Neumann 2009; 
Swynegedouw 1997). The key tenets of this debate have been to argue that scale is socially constructed and produced through social relationships and practice and they are therefore subject to constant re-negotiation and struggle (Perreault 2003). Social movements and other actors use scale as a strategic device to promote their cause at the most important level, seen by some as the process of "scaling-up" and by others with a more radical understanding of scale as shifting or jumping between scales constructing the local places as sites of political struggle. Perrault uses experiences of social movements in Ecuador to show how indigenous organising used spatial practices to constitute the local as well as multiscalar networks to link to an array of scales and actors. He argues that "careful attention to the organisations and multi-scalar processes that help produce place is vital for understanding the ways that indigenous people negotiate, and in various ways influence, political and economic transformation" (p83). Brown and Purcell (2005) argue that without an appreciation of theories of scale researchers may fall into the "scalar trap" where they assume that certain organisations, policies and institutions belong at certain scales and are more likely to have desired consequences at that level. They suggest that in the case of political ecology this has been the "local trap" where researchers have assumed that local democracy will yield the best results for environmental and social sustainability. They use a case study of the Brazilian Amazon to show how adopting an understanding of there being nothing inherent about scale would allow researchers to stop looking for reasons of why local devolution failed and allow a focus on the motives and strategies of those empowered by a shift in scale. McCarthy pushes the work on scale further arguing that there has been a relative lack of attention to the role of environmental NGOs in the construction of scales, and this requires a breaking down of the binary between environmental and social spheres (2005). McCarthy also argues that if scale is constructed it must also be contested; "contestation almost invariably draws upon and reinforces aspects of existing scales, while a successive progressive reconfiguration of scale for one group is often the construction of a new scale for domination for someone else" (p737

Work on social movements and transnational networks has also grappled with the issue of scale although this has tended to be within a binary framing of local and global issues. Transnational social movements, like the climate change networks I discuss here, are used by activists as institutions that can take issues out of specific localities into global 
arenas and struggles (see Baviskar 2002; Perreault 2003). Routledge and Cumbers describe the Global Justice Network through a series of globally organised meetings of movements such as the People's Global Action that provide a loose structure for a wide range of local struggles (2009). The actors in the GJN derive most of their strength from organising at the local and national scale and for most the global scale is not a significant field of action. The difference between the struggles of something such as the Global Justice movement and the Latin American experiences of indigenous organising and the emergent networks around climate change in India I discuss in this paper, is the lack of the immediate, explicitly labelled 'place based struggle' around which to organise. Whilst the farmers and trade unionists involved in something like People's Global Action might be experiencing local effects of climate change, the difficulty in labelling it as such and the existence of numerous other immediate explanations such as drought, land ownership, freak weather events, mean climate change is not yet a mobilising discourse at the grassroots level. This highlights a tension in coming at an issue with a "climate change lens", negotiating the reality of localbased struggles whilst using a global narrative that can supersede such struggles and construct a wider politics. In the context of climate justice, an appreciation of the politics of scale brings the international framing of the political space for justice claims into the research as an object of enquiry. This has been widely assumed to be the space for the best access to climate justice claims but has this missed other spaces by falling into the "global trap"? Whilst climate change has been conceptualised as a global environmental problem, it is mediated through multiple local problems such as water and food scarcity, disasters, or increased health burdens. The inherent scale of the environmental problem itself merits closer attention.

This paper therefore seeks to bring together aspects of the environmental and justice literature, development geographies and concepts of the politics of scale to outline the spatialities and shifting concepts of multiple climate justices. This serves to both deepen our engagement with how climate justice might be grounded in different communities and also to further an understanding of how a multi-scalar issue such as climate change justice crossing environmental and developmental issues might be conceptualised. The diagram below provides a framework for understanding how key concepts from the above literatures have been brought together to shed light on different aspects of climate justice. The 
diagram shows how the grounded experiences of justice and injustice (understood through the development literature) are refracted through a strategic use of scale (developed from the politics of scale literature) and result in certain targets for justice claims. The process of narrowing the multiple political claims for justice (conceptualised through environmental justice literatures) onto suitable targets for these claims, narrows down the space for multiple justices and the choice of scale can exclude certain claims. The diagram then shows how this choice of scale can become dominant, as this can become the de-facto target for justice claims and multiple justice claims are systematically neglected. Conceptualising climate justice in this way helps elucidate how diverse development experiences and multiple claims to justice become rescaled (currently at the international scale) and how this closes down political space for alternative articulations.

Figure 1: Conceptualising climate justice

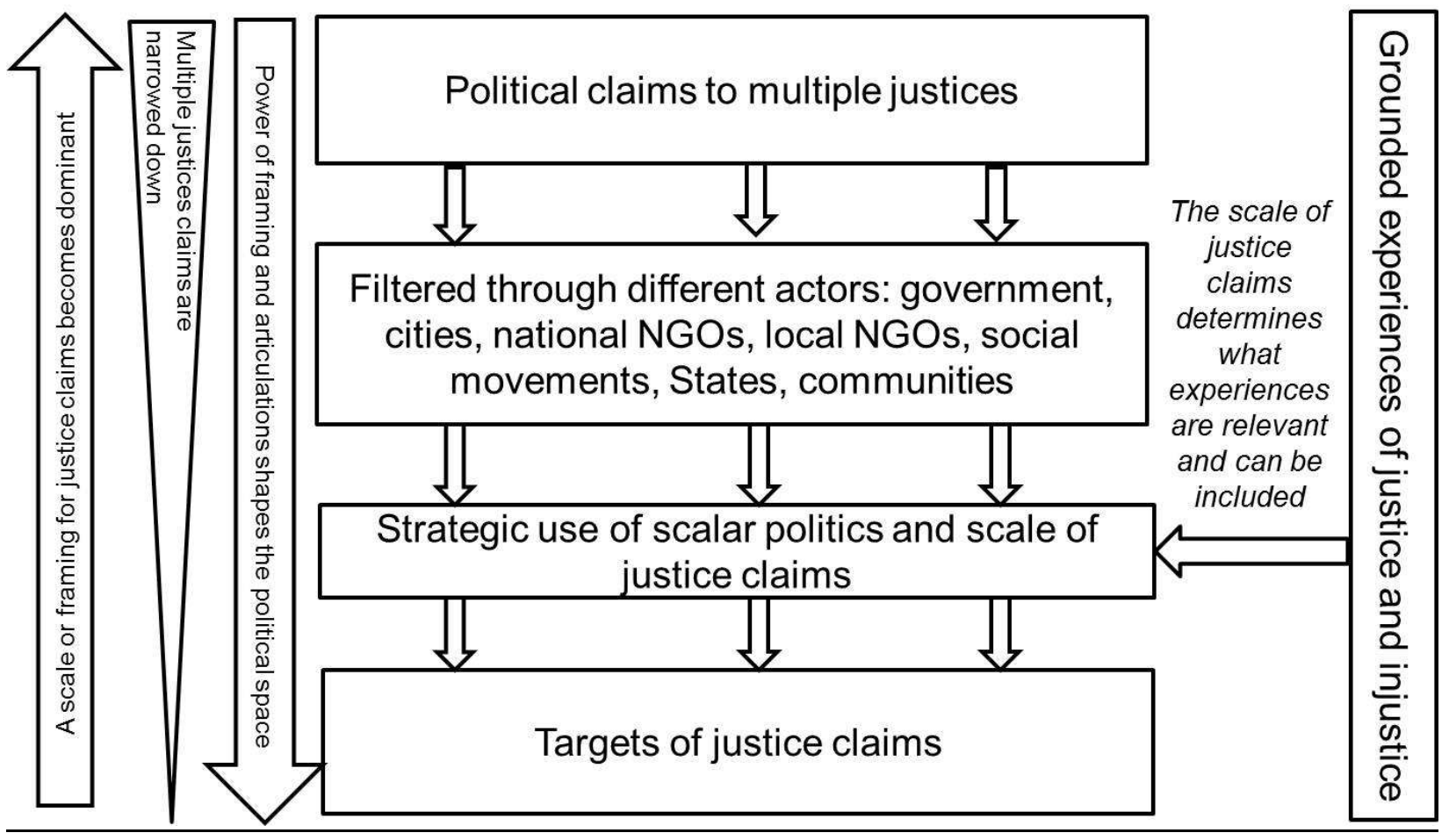

\section{Methodology}

This paper is based on 10 months fieldwork in India in 2008-2009, and 2 weeks research during COP 15 in Copenhagen. Research was undertaken with a set of NGOs and subnational actors engaging in climate change at local, national and international levels through loosely formed climate change networks to understand how climate justice was being 
operationalized by different actors beyond the nation-state. Research consisted of over 80 semi-structured interviews with key state and non-state policy actors, observation of participatory processes and programmes in villages and municipal governments, and content and discourse analysis of participatory outputs. This was complemented with a policy analysis of Indian government positions on climate change, both nationally and internationally. The empirical section of this paper is based on work with one particular civil society network. The network is made up of regionally-based NGOs working with marginalised groups or adivasi ${ }^{1}$.

I now go on to outline the history of justice and equity in the Indian debate and the role it has played in defining the international position on climate change and in national policy developments.

\section{The history of climate justice in India}

Prior to negotiations starting on the Framework Convention, the IPCC working groups produced the first assessment report of climate change in August 1990. The production of this document on the state of current scientific knowledge on climate change reflected many of the themes that would come to dominate climate negotiations for the following two decades. Southern countries felt they had been unable to participate due to a lack of capacity, and the report was seen to be produced almost entirely by individuals and governments from the global North. Indian delegates were dissatisfied with the report and what they saw as the agenda of the Northern countries to push through the assessment without due attention to Southern concerns (Rajan 1997). The principle of "common but differentiated responsibility" that first appeared in the IPCC first assessment became a statement of compromise between the North and South, reflecting the concerns for equity on the part of Southern nations (a point championed by India) and the reluctance of countries from the global North to assume total responsibility.

\footnotetext{
${ }^{1}$ Adivasi is an overarching term for a variety of ethnic groups considered to be part of the aboriginal population of India. Adivasi are recognised under the Indian Constitution as "Scheduled Tribes" and as such are recipients of certain affirmative action measures.
} 
India was an important player in developing the principle of Southern solidarity in climate negotiations and pushing for a united position framed around a North-South divide. Along with the "G77 and China" India developed a bargaining position around southern solidarity, holding a conference of Select Developing Countries in April 1990 to articulate a joint position. The "G77 and China" built and still maintains a position around the link between environment and development, financial resources, technology transfer, capacity building for negotiations and policy implementation and longer time scales for new regulation regimes (Vihma 2010).

The issue of equity in global emissions gained in prominence within India with the publication of a Centre for Science and Environment report (Agarwal \& Narain 1991) which sought to challenge a World Resource Institute (WRI) report on GHG emissions. The WRI report calculated surprisingly high GHG emissions for India, placing it fourth on a list of major contributors, putting pressure on India to engage in future mitigation attempts. In response Agarwal and Narain persuasively argued that a per-capita approach should be used rather than gross national emissions. They also argued that emissions should be divided into survival and luxury emissions, and high levels of methane gas production due to rice crops were directly linked to the survival of the millions of India's rural poor, whereas high emissions in the US for example were linked to high consumption lifestyles and luxury living. This report really brought equity to the forefront of the Indian negotiating position and established a pattern of North-South relations, which has continued within the UNFCCC framework. As Jakobsen argues, "the CSE report became a real eye opener not only for the Indian government but also for the delegations participating in the INC preparations for the UNCED. The CSE report was possibly the first attempt to bring consideration of equity into the emerging negotiations" (Jakobsen 2000 p281).

Over time the policy mechanisms under discussion have changed but India has built its stance around the sustained principles of 'common but differentiated responsibilities' emphasising no emission targets for non-Annex 1 countries, technology transfer, financial mechanisms to offset costs and the importance of binding targets for Annex 1 countries. Justice and historical responsibility for emissions continue to be cornerstones of the Indian negotiating position nearly twenty years later. Climate justice has been primarily 
constructed in international terms. It has become shorthand in the climate debate for the historical inequities between nations and a particular negotiating stance of the global South (Parks and Roberts 2008). India has been arguing for equity between nations in a historical perspective based on per capita emissions.

The international dimension of climate justice and the relationships between states has dominated the policy discourse as well as the academic attention. However, climate change has profound implications for domestic justice as well. Who will bear the costs of mitigation activities? Where will the effects of climate change be felt? How will these decisions be made? Domestic debate on India's climate change position has largely not focused on this internal issue due to concerns that internal divisions would undermine an internationally held position of southern solidarity and equity (Fisher 2012b). The first comprehensive climate change policy was released in June 2008. The plan focuses on eight key areas for concern: developing solar energy, increasing energy efficiency, securing sustainable habitats, water management, protecting Himalayan and glacier ecosystems, enhancing ecosystem services, making agriculture more resistant to climate change and setting up a strategic knowledge missions for focused research in this area. The formation of the National Action Plan has been criticised by domestic commentators for its lack of participation and vision (Thakkar 2009). Bidwai argues that the climate policy sphere has been an elite space of "closed door policy making... isolated from public scrutiny and participation and confined to a closed privileged environment" (2009 p49), and many looser networks are largely excluded from the tighter policy networks that directly contribute to the formation of government policy. The recent formulation of the NAPCC without civil society (or much interdepartmental) consultation, as well as the composition of the Prime Minister's Council on Climate Change indicates the very tight policy space and exclusive policy networks that have been formulating Indian climate policy (Bidwai 2009). In terms of climate justice these indicate the potential lack of space for recognition and procedural justice in the domestic sphere. Whilst these processes are still in early stages, the framing of climate justice as an international issue sidelined domestic climate justice concept in the domestic plan in terms of distribution, procedure or recognition.

Whilst policies of national governments and agreements reached under the United Nations 
Framework Convention on Climate Change (UNFCCC) have an important role to play, carbon emissions are also governed by many different actors (such as industry, cities and NGOs) that are making a difference at multiple levels and whose contribution needs to be further understood. This is no different in the field of climate justice. Whilst individuals within nation-state structures construct and present a unified policy position around equity, nonstate actors play an important role in debating and institutionalizing that within wider discourses. One attempt to open up the climate justice discourse was a report by Greenpeace India published in 2007 suggesting that in using the per capita approach the Indian government is hiding behind a large population of individuals living below the poverty line which masks larger emissions on the part of the urban middle and upper classes (Ananthapadmanabhan et al. 2007). This report was not well received within India due to its threat to the international discourse of equity and Greenpeace India has since distanced itself from this position. This highlights the difficulties for non-state actors seeking to build on the international justice framing to pose questions re-scaled in new spaces.

Other NGO positions do focus more specifically on domestic justice concerns. The regional network of NGOs positions justice claims centrally in its response to climate change in its mission statement stating that "The issue of Climate Change raises basic questions of social and environmental justice and has a direct bearing on development alternatives for the future" (Network publication 2009). In 2009 the network sought to build a bigger coalition called around climate justice under which events in the build-up to COP 15 (Copenhagen) were organised. The key difference with this position and that of the government is the emphasis on national justice claims as well as international equity. The regional network group the Indian elite with the international community as perpetrators of climate injustices and position the local communities as the site of solutions. This heavy emphasis on the Indian elite and consumption patterns is a key area of difference between the network position and that of the government. Despite this work of contestation of scale by the network to seek to broaden the concept of climate justice locating justice claims within the nation-state and re-scaling solutions to local communities, the public discourse remains dominated by the international dimension (shown in the media, government policy and other NGO positions). As will be seen in the next section, the network found it difficult to operationalize this rhetoric of spaces for national climate justice claims. Within the 
international climate negotiations themselves the regional network (and other NGOs) do not emphasise these alternative framings and scales through a need to support the Indian government in the wider struggle for southern solidarity and international equity (Fisher 2012b). Even whilst internal debate within the civil society networks had turned to domestic equity issues to a limited extent, there was no political space to air these concerns due to the dominant concern of how internal divisions would be perceived internationally.

Thus far, we can see that spaces for climate justice have been largely constructed as at the international scale and this has been a key part of the Indian negotiating position. Whilst some NGOs have started to critique the national position and the inequality within India, and sought to re-scale and contest this framing this has yet to make a serious impact on the public discourse, and is not articulated in the international arena. I now go on to show how this scaling of the space for climate justice claims became institutionalized in the work of the regional NGO network and how this process closed down spaces for alternative articulations and spaces for climate justice claims.

\section{Local participatory processes for climate justice}

Beyond these international and national conceptualisations of climate justice, local communities are beginning to be involved in climate change issues through NGO participation efforts, government programmes or multilateral/bilateral agency projects. The following section looks at one instance of a participatory process to engage marginalised communities in international climate politics through the wider coalition for climate justice organised by the regional NGO network. I suggest that through this example the institutionalisation of the international scale of climate justice can be clearly seen through the structure and nature of the participatory processes. This also shows how alternative articulations are neglected or pushed to one side as they are subjected to the re-scaling to the international space.

In the six months prior to COP 15 the regional NGO network set up a series of engagement processes to bring the voices of marginalised communities to the UNFCCC COP 15 in Copenhagen. The activities organised were: a set of public hearings organised in six 
different ecosystems, culminating in a three-day national hearing in Delhi and a presentation of the hearings through several videos at side events at COP 15; a day event in Delhi held as a consultation with grassroots groups and a youth convention in rural Andhra Pradesh. Each of these processes resulted in political charters, calls for action and future plans for tackling climate change within the local communities. These were presented to local Members of the Legislative Assembly (MLAs), distinguished guests (from law, civil society and government) in Delhi, and mixed audiences at COP 15. Other outputs included knowledge sharing of protest and adaptation strategies among the communities, as well as knowledge transfer about the local contexts to national decision makers. The NGOs in their external framings of the hearings portrayed participants as low emitting communities who "are the reason for India's low carbon footprint" and "in the national and global discourse their voices are not heard" (Network publication 2009c).

Content analysis of discussion notes and participatory processes show that groups at the local level understandably have a limited knowledge of what climate change is. Groups were asked to reflect on their experiences with climate change as well as potential solutions. As well as the issues that could be related to climate change, most groups also mentioned other development problems such as: lack of urban infrastructure; rural-urban migration; corruption; falling number of small ruminants; forest cover decreasing; farmer suicides; loss of cultural values; and effects of large development/industrial projects. As well as the focus groups in the youth consultation, the public hearings also collected a number of individual testimonials. These testimonies of local experience were then reframed within the charters and other outputs to be used by the NGO staff for political campaigning. The charters were created as political documents by the network organisations involved, to be presented to national politicians and policymakers. The charters also included references to many of the local development problems that people brought up, but the language used links them more explicitly to climate change and structural inequality. Analysis of these documents shows a greater focus on the national and international political dimensions of climate change than in the testimonials. The charters also introduced two concepts that are not mentioned at all in the testimonials: local people as resilient, and local people as living in harmony with nature. Another framing to emerge from the Charters is the resilience of local people and their role as "change agents". Whilst none of the testimonials reflected an 
understanding of resilience or local people as holding agency or power, the language in the Charters deliberately creates a more resilient image of the communities. For instance they describe how, "poor women and men are coming together to change the patterns of agriculture, use organic inputs, switch to agro-forestry and mixed farming, set up grain banks" and "people are raising the banners of protest against a global development paradigm" (Network publication 2009a). Many of the testimonials were focused on multiple development issues, including significant destruction from industry, large development projects, and multinational companies. In the Charters, these issues are included but the writers have tried to link the issues to a broader development paradigm that contributes to climate change. For example, in discussing water the language of the general Charter notes that "we are in a country already where safe water availability, even for domestic and livestock needs is in a crisis situation" (Network publication 2009b) and "the situation in urban India has been aggravated by the increasing temperatures and erratic rainfall leading to floods. The mindless development of expressways, shopping malls and unplanned construction activities aggravates the situation" (Network publication 2009a). The involvement of the communities in such processes is often left obscured. For example the workers are referred to as "not responsible for climate change as they are not controlling the means of production. Workers have the right to be informed about the production process and to be allowed to bargain for a production process based on lower carbon footprints" (Network publication 2009b). This frames a particular relationship between the workers in the mining or manufacturing centre and the production process, suggesting that the workers could be in a position where they would have the power and the inclination to prioritise low carbon production over improving their own livelihoods. This view was not seen in any of the local discussions or testimonials.

The embedded international scale in the climate justice discourse influences how local processes and programmes on climate change are framed and enacted. In organising these participation events and climate hearings in the run up to COP 15, the NGOs have started with the global discourse of climate change and have tried to link it back down to placebased struggles, for democratic legitimacy in international negotiations and also to add depth to an understanding of what this will mean in the Indian context. This is shown by the 
setting of several of the capacity events, which seek to give information on international climate change, and then asking people to make connections. This is in contrast to hearing the local stories first and considering what broader narratives they might speak to. This leads to a reversal of the sense of place in the network. The global level is the point of reference and where the staff locate their claims for climate justice. This can lead to perceived local injustices bring redefined as part of a wider national injustices (per-capita emissions for example) to ensure a match with the global discourses of the UNFCCC.

The main NGO in the regional network involved in the participatory processes paid considerable attention to mobilising government attention in Delhi. However, the placebased struggles of the adivasi and other marginalised communities that were well articulated through the testimonials, brought up tensions between a politically strategic discourse of international equity and local experiences of structural inequality. To make the political leap to wider discourses of climate justice the inherent tensions between different levels of abstraction were left unarticulated or smoothed over through the process of linking to higher abstractions in political documents such as the Charters. For example the structural inequalities the adivasi suffer that makes them particularly susceptible to climate change impacts (see Baviskar 1995 for a discussion of these) are not directly linked back to government processes but reframed as part of international climate injustices. This effectively neutralises the political messages and climate justice claims of the individual stories, as the point of struggle is relocated at the NAPCC document or the UNFCCC negotiations. There is an attempt to impose a 'global politics' on people embedded in the particularity of their own struggles. Harvey argues that "transformations of space, place and the environment are neither neutral nor innocent with respect to practices of domination and control. Indeed, they are fundamental framing decisions - replete with multiple possibilities - that govern the conditions (often repressive) over how lives will be lived" ((Harvey 1973 p44). The transformation of local struggles into a global narrative of climate change is not without its tensions and contradictions and as Harvey suggests, the participation processes risk being part of a wider system of domination and control. 
The participatory processes highlight a tension for the NGOs involved in re-scaling a targeted political message at national and international levels and bearing true representation (procedure and recognition) to the messages that have come out of participation. This example shows the reversal of the concept of place in the process, and the lack of an effective place-based politics from which the networks seek to engage in a rescaling of local development issues and experiences into a strategic international justice claim. The space for climate justice claims is shaped by the international discourse around climate change, both in terms of it being a global problem, and having global solutions.

\section{Discussion and conclusions}

This paper so far has shown how state and non-state actors construct ideas of climate justice across different spaces from the international regime, to national policymaking spaces and rural participatory processes. I now go on to make three arguments about the implications for conceptualising climate justice and argue for the need to develop a more spatially grounded understanding and opening political space for multiple climate justices. Firstly, I argue that climate justice has been constructed as an international ideal and been implicitly and explicitly understood as the relationships between nations. This has obscured a further understanding of the national and local justice implications of climate change. Secondly, I suggest that the role of state and non-state actors in constructing this ideal and prioritising some aspects of climate justice concepts needs to be examined further and insights from development literature can be insightful here. Finally, drawing on work on environmental justice and the politics of scale, I suggest that there are multiple claims to climate justices occurring across scales and actors engaging in climate change work must open up their constructions of justice to take account of the local and national ramifications, to prevent the systematic neglect of these claims in new systems of policy and politics. These three arguments lead me to conclude that conceptualising climate justice claims as the product of spatially grounded experiences refracted through political processes of scale construction opens up an analytical space to consider the multiple justices that do not make the political agenda as it is currently conceived. 
The international equity argument has been central to the Indian international position on climate change and is part of a wider foreign relations orthodoxy built around southern solidarity (Rajan 1997). Beyond the nation-state there has also been widespread agreement of this position of equity within both the media and wider civil society (Dubash 2009; Fisher 2012b). Whilst this position may well be justified given the external pressures and the historical responsibility of the Northern nations for emissions, this focus on the international scale as the primary arena for climate politics and climate justice has excluded debates on how climate change will impact national and local justice issues. Non-state actors such as Greenpeace India who suggested alternative framings of the justice paradigm, were critiqued for puncturing the discourse of southern solidarity and therefore risking the efficacy of the equity message internationally. Other NGOs such as the regional network discussed in this paper struggle to successfully contest the dominant framing of international climate justice despite an attempt to widen the national debate. The international discourse has largely focused on the call for equity, although both distributional and procedural aspects have been contentious issues. Nationally, climate change policy processes that have been recently instigated have been suggested to be lacking in procedural justice or not developing a policy framework attentive to the effect of climate change on existing inequalities (Bidwai 2009). Climate change policy (both international and national) has been widely cited to be exclusionary and practised by a small number of individuals. Whilst this is not unique to India, and certainly not in the area of foreign affairs, as climate change begins to become closer to home, the impacts on diverse communities and on wider development processes will become more significant and the justification for an elite policy sphere becomes more difficult to maintain. The national policy development has, however so far, been done in reference to international processes and requirements and due to this positioning outside national issues of inequality has not received the sustained pressure for wider participation that other public issues in India have over the past decade (for example the Right to Food movement, or the Right to Information). As the issue becomes more important to development concerns in India this involvement will increase however, and the potential for multiple climate justices will become more important. 
Participation in policy processes can be divided into the 'invited spaces' created by the policymakers or structures and 'claimed spaces' created by non-state actors themselves (Brock et al. 2001). In the above example the networks have sought to claim their own space for bringing unheard voices and new individuals and groups into the climate debate but they have done so under the shadow of the 'invited spaces' at different levels. Knowing the hearings would feed into the UNFCCC process, as well as specific organisational ideologies and histories, led to the use of certain framings by the organisers even within what seemed to be 'claimed spaces' of resistance. This process of seeking to bring the roots of the networks into global processes has sought to address the gap in representation of marginalised communities in the national delegation, and through "forum shopping" give the voices of the marginalised in India maximum power and agency. However, multiple claims for developmental and environmental justice many of which have a climate element are sidelined as the re-scaling privileges those framings that will resound with an international scale.

I have argued so far that state and non-state actors seek to situate and re-scale their claims for climate justice at the international level. Through this process the scale becomes institutionalized as the appropriate one for climate justice claims and spaces for alternative articulations are closed down. This narrows down the kind of climate justice claims that can be articulated as only those with reference to the international scale can be re-scaled in this framing.

\section{Role of the state and non-state actors}

The role of the state in instigating and resolving issues of environmental justice has been somewhat side-lined in environmental justice literature that has privileged the role of capital. However, as Williams and Mawdsley (2006) argue this perspective has not taken enough account of the fact that the post-colonial state is built on the "colonial states [that] were usually designed more to impose order and extract resources than to instil public trust, and this institutional legacy has lived on after Independence" (p663). Conversely, concepts of climate justice have positioned the nation-state as the sole actor of negotiating justice for the nation; however this has stopped short of considering how the actions and 
positions of the national government might impact on national or local climate justice issues. The case of India demonstrates that the nation-state can hold the position of both champion for international climate justice and the potential perpetrator of national injustices such as a lack of procedural justice in policy formation or emphasis on distributional issues in mitigation policies or future impacts.

Literature on development and experiences with the state has much to add here to understandings of locally rooted injustices (see for example Corbridge et al. 2005; Mawdsley 2006; Ferguson 1990). As Baviskar suggests the role of the state in recreating injustices for the adivasis population in India has been significant; she argues that "the failure of the welfare state to substantially improve the lives of adivasis is evident in their impoverished everyday lives. Deprivation is not a natural state for adivasis; it is produced and reproduced by the policies and practices that characterize India's post-colonial development (Baviskar 2005 p7). However, despite this acceptance within wider literatures that the state itself mediates vulnerability to hazards and poverty, concepts of climate justice have not so far grappled with the potential dual role of the state as both a champion of justice and a perpetrator of injustice. The state may be a key actor in embedding conditions of poverty and structural inequality that give rise to climate vulnerabilities. However, as shown in the discussion of NGO participatory processes the state is not the only actor in climate change governance and geographers need to examine more critically how non-state actors reconstruct scales of justice claims in their engagement with climate change politics. Instances of procedural justice and lack of recognition involve both state and non-state actors at multiple scales.

\section{Spaces for multiple climate justices}

To really consider what claims for climate justice might mean beyond international processes we must know what that means locally and nationally. One way to do this would be to link more explicitly to debates on environmental justice and development processes to have a more grounded understanding of the experiences of climate (in)justices in the global South. Climate change justice has been powerfully framed as a singular discourse and analytical concept by the epistemic communities of the IPCC and the UNFCCC, that have sought to isolate an idea of climate justice that is additional to existing structural 
inequalities. As such, it has focused on distributional aspects (termed equity) and the relationships between nations. However, as empirical work on vulnerabilities to the effects of climate change repeatedly show, exposure to climate risks is mediated through existing institutions and histories of disadvantage (Mason 2011; Paavola and Adger 2006). As the participatory processes discussed show, marginalised communities experience a range of issues pertaining to development, environmental degradation, caste systems and others. Many of these issues will be worsened by climatic change, or may be linked to policies relating to climate change (forestry for example) and the international negotiations are not the only political space for these claims. Local development processes and decisions have more proximal agents, and climate change is a stress multiplier, but not necessarily the only source of stress for these claims. Environmental justice has been recognised to exacerbate the tensions of race, class or gender but analyses construct these traditional structural inequalities as part of a wider environmental injustice. Discussions of climate change justice on the other hand, have tended to side-line such issues (Pelling 2011). Pelling argues that adaptation to climate change can be both resilience to maintain existing unequal structures, or a way to transform long-standing social relationships. However, the current mode of conceptualising climate change adaptation within the UNFCCC for example conceives of climate justice as the resilience of existing social systems rather than the transformation to new more equal societies. This raises the question if such a monolithic concept of climate justice can accurately capture the varied experiences of relationships between local communities, state and non-state actors locally, nationally and internationally and across these scales. There are multiple, spatially grounded experiences of claims for climate justice that are intimately bound up with histories, power and politics of development. The isolation of climate justice as an international issue, also leads to its separation from the pressing concerns of Indian activists or social movements despite many commonalities for the people whom these movements seek to represent. Development will be harsher under new climatic conditions and the concerns of such movements will become more pressing. The potential for climate justices or injustices in national climate policies for mitigation, funding and distribution for adaptation, and procedures for national and international policy will impact on local communities, interacting with their current experience of development. Climate justice is therefore part of a lived experience of multiple justice claims: both environmental and developmental, involving both state and non-state actors, and a 
comprehensive understanding of a just way to respond to the challenge of climate change must recognise the multiple spatialities of the concept.

I have argued in this paper that the concept of climate justice has emerged as part of the international debate over inter-state responsibilities and North-South relations over climate change but has so far lacked a more nuanced deconstruction of what is meant by climate justice beyond the international negotiations, neglecting to address who will seek to access climate justices at different scales, and which actors contribute to scaling claims for climate justices. This requires an analysis that goes beyond a distributional focus, the equity terminology often used in climate debates, to explore the distribution, recognition and participation of different actors across different spaces. I show through a discussion of the role of justice and equity in international negotiations, national policy spaces and local engagements with climate change, that to fully understand and conceptualise the implications of climate change justice insights from environmental justice, development research and understandings of scale are necessary. Geographers are in a strong position to open up this debate and to move beyond the largely static ideal of climate justice to explore its multiple manifestations and the ways in which different scales contradict or support each other in the search for climate just solutions.

\section{Acknowledgements}

I am grateful for an ESRC PhD award, a Darwin College Travel award and a Smuts Memorial Grant that allowed me to undertake this research as well as current support from the Grantham Research Institute on Climate Change and the Environment, LSE and the Centre for Climate Change Economics and Policy (CCCEP) which is funded by the ESRC and by Munich RE. I would like to thank all my research respondents for their time and insights into this topic. Thanks to Emma Mawdsley (University of Cambridge) for support and guidance during the research and to Richard Perkins and Michael Mason (LSE) for comments on earlier drafts of this paper. As ever, all errors and omissions are my own. 
Adamian M 2008 Environmental (in)justice in climate change in Vanderheiden S ed Political Theory and Global Climate Change, MIT Press, Cambridge, MA

Agarwal A and Narain S 1991, Global warming in an unequal world, Centre for Science and the Environment, New Delhi

Ananthapadmanabhan A, Srinivas K and Gopal V 2007 Hiding behind the poor: a report by Greenpeace on climate injustice, Greenpeace India, Bangalore

Baviskar A 2002 In the belly of the river: Tribal conflicts over development in the Narmada Valley Oxford University Press Delhi

Baviskar A 2011 Spectacular events, City Spaces and Citizenship: The Commonwealth games in Delhi in Shapiro-Anjaria J and McFarlane C eds Urban Navigations: politics, space and the city in South Asia, Routledge, New Delhi 138-161

Bidwai P 2009 An India that can say yes: a climate-responsible development agenda for Copenhagen and beyond Heinrich Boll Foundation New Delhi

Brock K, Cornwall A and Gaventa G 2001 Power, knowledge and political spaces in the framing of poverty policy Working Paper 143 IDS, Sussex

Brown CJ and Purcell M 2005 There's nothing inherent about scale: political ecology, the local trap, and the politics of development in the Brazilian Amazon Geoforum 36 607-624

Castree N 2010 Neoliberalism and the biophysical environment: a synthesis and evaluation of research Environment and Society: Advances in Research 1 5-45

Chambers R 1990 Rural appraisal: rapid, relaxed and participatory, Discussion Paper 311, IDS Sussex

Chatterjee P 2004 The Politics of the Governed in Chatterjee P ed The Politics of the Governed, Columbia University Press, New York 53-78

Cooke B and Kothari U 2001 Participation: the new tyranny? Zed books London

Corbridge S, Williams G, Srivastava M and Veron R 2005 Seeing the State: Governance and Governmentality in India Cambridge University Press Cambridge

Dubash N 2009 Towards a progressive Indian and global climate politics, Centre for Policy Research Climate Initiative, Working Paper 2009/1, New Delhi

Featherstone D 2003 Spatialities of transnational resistance to globalization: the maps of grievance of the Inter-Continental Caravan Transactions of the Institute of British Geographers 28404

Ferguson J 1990 The anti-politics machine:development, depoliticisation and bureaucratisatic power in Lesotho CUP Cambridge

Fisher S 2012a India and climate change: equity, energy and development in Bailey I and Compston $\mathrm{H}$ eds Feeling the Heat: the politics of climate policy in rapidly industrialising countries, Palgrave Macmillan, Basingstoke 123-148

Fisher S 2012b Policy storylines in Indian climate politics: opening new political spaces? Environment and Planning C: Government and Policy 30 109-127

Fraser N 2000 Rethinking recognition New Left Review 3 p107-120

Gadgil M and Guha R 1995 Ecology and Equity: the use and abuse of nature in contemporary India Routledge London

Guha R and Martinez-Alier J 1997 Varieties of Environmentalism: Essays North and South Earthscan London

Harvey D 1973 Social justice and the City John Hopkins University Press Baltimore

Hickey S and Mohan G 2004 Participation: from tyranny to transformation? Exporing new approaches to participation in development, Zed books, London

Network publication 2009a National Civil Society Coalition for Climate Justice and Equitable Development: Community Charter

Network publication 2009b National Civil Society Coalition for Climate Justice and Equitable Development: General Charter 
Network publication 2009c People's Voices in the Domestic and International Climate Change Agenda: Advocacy Booklet

Jakobsen S 2000 Transnational environmental groups, media, science and public sentiment(s) in domestic policy making on climate change in Higgott R, Underhill G and Bieler A eds Nonstate actors and authority in the global system, Routledge, London 274-289

Li T 2007 The Will to Improve Duke University Press London

Marston SA 2000 The social construction of scale Progress in Human Geography 24 219-242

Mason M 2011 The ends of Justice: Climate vulnerability beyond the pale in Held D, Theros M and Fane-Hervey A eds The Governance of Climate Change, Polity, Cambridge p162-182

McCarthy J 2005 Scale, Sovereignty, and Strategy in Environmental Governance Antipode 37 731753

Mohan G and Hickey S 2004 Relocating participation within a radical politics of development: critical modernism and citizenship in Hickey $S$ and Mohan $\mathrm{G}$ eds From tyranny to transformation? Exploring new approaches to participation in development, Zed books, London

Mosse D 2005 Cultivating Development: an ethnography of aid policy and practice Pluto Press London

Neumann R 2009 Political Ecology: theorizing scale Progress in Human Geography 33 p398-406

Newell P and Paterson M 2010 Climate Capitalism: Global Warming and the Transformation of the Global Economy CUP Cambridge

Nussbaum M 2006 Frontiers of justice: disability, nationality, species membership Belknap press Cambridge, MA

Okereke C, Bulkeley H and Schroeder H 2009 Conceptualising Climate Governance Beyond the International Regime Global Environmental Politics 9 58-78

Paavola J and Adger WN 2006 Fair adaptation to climate change Ecological Economics 56594

Page E 2006 Climate change, justice and future generations Edward Elgar London

Parks BC and Roberts JT 2008 Inequality and the global climate regime: breaking the north-south impasse Cambridge Review of International Affairs 21621 - 648

Pelling M 2011 Adaptation to climate change: from resilience to transformation Routledge London

Perreault T 2003 Changing places: transnational networks, ethnic politics, and community development in the Ecuadorian Amazon Political Geography 22 61-88

Posner E and Weisbach D 2012 Climate Change Justice Princeton University Press Princeton, NJ

Rajan MG 1997 Global Environmental Politics: India and the North South Politics of Global Environmental Issues OUP Delhi

Routledge P and Cumbers A 2009 Global Justice Networks: Geographies of Transnational Solidarity

Schlosberg D 2004 Reconceiving Environmental Justice: Global Movements And Political Theories Environmental Politics 13 517-540

Schlosberg D 2007 Defining Environmental Justice OUP Oxford

Scott J 1985 Weapons of the weak: everyday forms of peasant resistance Yale University Press

Sen A 2009 The Idea of Justice Penguin Books London

Shah A 2010 In the Shadows of the State: Indigenous Politics, Environmentalism, and Insurgency in Jharkhand, India Duke University Press Durham

Soltau F 2009 Fairness in international climate change law and policy Cambridge University Press Cambridge

Swynegedouw E 1997 Excluding the other: the production of scale and scaled politics in Lee R and Wills J eds Geographies of economies, Arnold, London 167-176

Sze J and London J 2008 Environmental justice at the crossroads Sociology Compass 2 1331-1354

Thakkar H 2009 There is little hope here: a civil society view, The South Asia Network on Dams, Rivers and People, New Delhi

Veron R 2006 Remaking urban environments: the political ecology of air pollution in Delhi Environment and Planning A 38 2093-2109 
Vihma A 2010 Elephant in the room: the new G77 and China dynamics in climate talks, The Finnish Institute of International Affairs, Helsinki

Walker G 2009 Beyond Distribution and Proximity: Exploring the Multiple Spatialities of Environmental Justice Antipode 41 614-636

Williams G and Mawdsley E 2006 Postcolonial environmental justice: government and governance in India Geoforum 37 660-670

Young I 1993 Together in Difference in Squires J ed Principled Positions: Postmodernism and the Rediscovery of value, Lawrence and Wishart, London p121-150 